\title{
The Expert Systems and Their Role in Developing External Auditor's Performance and Improving Audit Service's Quality in Information Technology Environment in Audit's Offices Located in the Hashemite Kingdom of Jordan
}

\author{
Reem Okab ${ }^{1}$ \\ ${ }^{1}$ Department of Financial \& Administrative Sciences AL-Huson University College, AL-Balqa' Applied \\ University Jordan, Jordan \\ Correspondence: Reem Okab, AL-Balqa' Applied University Jordan, AL-Huson, P. O. 676, Jordan. E-mail: \\ medoheart2000@yahoo.com
}

Received: May 8, 2013

Accepted: June 13, 2013

Online Published: August 10, 2013

doi:10.5539/ijbm.v8n17p129

URL: http://dx.doi.org/10.5539/ijbm.v8n17p129

\begin{abstract}
The study aimed at identifying the role of using expert systems in external audit's operations through determining the benefits accrued from using the expert systems like speed and accuracy of planning audit operation, training of the new auditors and availability of database that helps the new auditors in order to make decision pertaining to audit operation. This study stated the role of the expert systems in developing the occupational performance of auditor, contributing to improve the evaluation of audit risks, confirming the rationality of accounting estimates related to some items of financial statements and achieving audit services' quality. It alsoidentified the most important limits the application of expert systems face through audit's operation.

The study found that auditors are aware of the importance of using expert systems in audit operation in information technology environment, and they also understand that using such systems contributes to develop auditor's performance and improve audit services' quality.
\end{abstract}

Keywords: expert systems, external audit, e-audit, audit quality, audit's offices

\section{Introduction}

Artificial intelligence represents one of computer programs which deal with inputs pertaining to a certain field. Human mind also deals with such programs through operational processes the computer are fed with according to certain conditions in order to reach to arbitral results which are similar to those the human mind reach away from the special fancies. The expert systems are one of artificial intelligence softwares which rely on bias and heavily on two components related to knowledge base and a set of sub-softwares which enable one to form the rationality of thinking and makethe optimal decision of a certain issue and problem according to the inputs they are fed with and outputs targeted. In audit's field, expert systems are considered computer programs consisting a knowledge and experience acquired from one or more experts of audit. And they are designed in a way simulating the methods of think and the rules of making decision which the auditor follow in a certain field in order to be able to solve certain problems. Using expert systems helps to solve audit's problems in particular unstructured problems which do not have a clear path or critical method for making the decision pertaining to them; this is due to their statutes. In order to benefit from the advantages and possibilities of information technology including expert systems, auditors have to have a high level of scientific knowledge and cognitive skill of using such system of audit field.

\subsection{The Importance of Study}

The importance of study is derived from addressing a new subject which the researchers rarely study. It is the use of expert systems in audit, their contributions of developing auditors' performance and increasing their capability. 


\subsection{The Purposes of Study}

This study aims at:

- Identifying the definition of expert systems and their importance of performing external audit operation.

- Identifying the importance of using expert systems in audit.

- Identifying the fields of using the expert systems in audit in information technology environment.

- Identifying the role of expert systems in developing auditor performance and increasing his $\backslash$ her capability in information technology environment.

- Identifying the role of expert systems in improving external audit services' quality in information technology environment.

\subsection{The Problem of Study}

The problem of study is emerged from answering the following questions:

- Do auditors understand the importance of using expert systems in audit in information technology environment?

- Does the use of expert systems in audit contribute to improve auditor performance in information technology environment in the Hashemite kingdom of Jordan?

- Does the use of expert systems in auditlead to increase audit quality in information technology environment in the Hashemite kingdom of Jordan?

- Are there limits which hinder the use of expert systems in audit in information technology environment in the Hashemite kingdom of Jordan?

\subsection{The Hypotheses of Study}

In order to achieve the purpose of study, the following hypotheses will be tested:

- The auditors in the Hashemite Kingdom of Jordan understand the importance of using expert systems in audit in Information Technology environment.

- Using expert systems in audit operation does not contribute to improve auditor performance in Information Technology environment in the Hashemite Kingdom of Jordan.

- Using expert systems in audit operation does not lead to improve audit quality in Information Technology environment in the Hashemite Kingdom of Jordan.

- There are limits which hinder the use of expert systems in audit in information technology environment in the Hashemite kingdom of Jordan.

\section{Theoretical Frame}

Expert systems are used in all fields and domains and at all stages of solving the problems. However, the use of such systems are still little and limited due to the cost of developing them and the difficulty of using, updating and maintaining them. Indeed, they have been used within the administrative organizations and achieved the benefits in the processes of establishing the purposes of strategy, planning, designing and making the decisions, as well as checking and following-up.

The expert systems represent one of the most important artificial fields; an experience means a great acquisition of procedural knowledge and skill which lead to perform distinctively the determined qualitative missions the expert doesin a certain field (Othman, 1998, 129). The expert systems were identified as "a system built on a knowledgement designed in order to model the ability of human expert of solving problems, and they are one of developed artificial forms based on a principle similar to the logic of human thinking in order to build such systems (Yasin, 2000, 29).

The expert systems in audit can be defined as "the intelligent programs consisting of a acquired knowledge and experience (including database) i.e stored information acquired from an experienced auditor; they are designed in a way simulating the methods of think and the rules of making decision which the auditor follow in a certain field in order to be able to solve new problems and make a decision in audit operation.

Using the expert systems in audit requires that the auditor classifies the missions of audit operation according to the degree of structuring which is as follows (Mohammad, 1999, 214):

-Structured missions: They are the missions which can formulate clearly a problem at the stage of 
understanding or planning, they consist of elements and relationships between the elements and all of them can be understood. These structural decisions address repeated routine problems; and they have a known routine procedure. Such decisions are well determined and clear and need a low level of personal judgment and evaluation.

- Semi-structured missions: they are the missions which include some elements and relationships that can be understood, identified and finally defined reasonably. In addition, the alternative solutions used for completing these missions are limited; this allows the decision maker to make personal judgment and evaluation regarding choosing the alternative solutions.

Unstructured missions: they are the missions which can not formulate clearly the problem at the stage of understanding, or the stage of planning. Thus, the personal evaluation of auditor is required for choosing the best alternatives at the stage of choice; the unstructured decisions address new unrepeated problems and have no a clear path or critical method of making decision due to its status where its nature and structure is ambiguous or complicated.

Audit missions may place in the previous missions such as the scope of structured missions while making the decision pertaining to determine the size of a sample or establish audit program i.e the routine missions and semi-structured missions which are considered a huge scope for use. In such scope, the auditor has a freedom of using these systems of audit. Regarding the unstructured missions, they are considered the most important fields which enable the audition to use the expert systems where the technique of expert systems helps to confront the problems of incapability and weakness of performing audit missions. The unstructured missions of audit include the following: (1) the evaluation of continuation, (2) the estimate of loans' losses in banks and allocations required for covering the obligations, (3) the estimate of debts' doubtful allocation, (4) the reasonableness of evaluation, and (5) the evaluation of internal control system.

Using the expert systems in external audit is important in information technology environment in order to achieve the following purposes (Lutifi, 2005, 4, 29):

- The expert systems help to protect the human knowledge from loss and damage and to maintain the occupational experience of various specialized fields of audit's offices. The experiences and practices are documented within the expert systems and added to such systems if necessary. Hence, the expert systems are considered a trustworthy warehouse of this experience.

- The expert systems contribute to improve the productivity of auditors so that the technical experience the auditor acquired is at the disposal of new accountants as well as other accountant to take its advantages.

- The human experience is published and distributed among the employees of audit's offices at a low cost.

- The expert systems increase the ability and capability of making the compound and complicated decisions through using a huge amount of details, data and facts which require an expert of audit field.

- The expert systems help to understand deeply a knowledge; this makes the experts of audit's office able to review their practices in addition to assist the beginners in order to acquire the knowledge and use these systems as training backsides.

2.2 The Advantage of Using the Expert Systems in External Audit Operation Which Contributes to Improve Audit Service Quality in Information Technology Environment

The expert systems used by auditors contribute to overcome the problems which they face during the process of performing audit mission in information technology environment. They also achieve the follow advantages of audit operation (Al-Shadli, 2004, 121) which contribute to improve audit quality:

- Using the expert systems leads to accelerate the performance of audit missions because they depend on computer. Consequently, audit missions can be performed at the determined right time.

- $\quad$ The expert systems help to rationalize the personal judgment and evaluation of auditor in information technology environment, where the auditor reaches objectively to the decision which is built on the base of a programmed knowledge within the system.

- The expert systems help to increase the degree of trust of auditor's report where they contribute to rationalize the personal judgment of auditor because it has been prepared by a capable auditor for performing audit missions in information technology environment.

- Using the expert systems contribute to decrease the costs of audit operation because of the speediness of performing such mission. In addition, there is no need to extra time and the costs associated with making 
improper decisions are avoided; this is due to system's objectivity and accuracy of reaching to these decisions.

- The expert systems help to increase audit operation's quality in information technology environment. This can be occurred through assistance of planning a proper program of audit, decrease of time, effort and cost. In addition, a report with accuracy and trust guarantee must be submitted. The expert systems help to choose properly the evidence of reliability and decrease uncertainty status i.e decrease the rate of audit risk.

- $\quad$ The expert systems address the problem of scarcity of experienced auditors specialized of performing audit missions where the expert system help to train the new auditors and help the auditors to acquire quickly the experience.

- The expert systems help to solve the structured problems which are repeated and routine and the unstructured problems which have no clear path or critical method of making decision pertaining them due to their compound or complicated status and structure. Thus, the expert systems help to achieve effectively and efficiently audit processes.

\subsection{Expert Systems and Their Role in Developing External Auditor's Performance}

Using the expert systems contributes to developing the occupational performance; the contributions of such systems can be summarized by the following points:

- The expert systems help to improve the capability of auditor in information technology environment. This can be occurred by the assistance of making decisions through the stored information and knowledge base which built on the stored experience of auditor.

- The expert systems are considered the best methods for training the employees of audit offices where inexperienced auditors can be guided to the information which must be taken into consideration in order to reach a certain decision.

- $\quad$ The expert systems help to improve decision's quality which the auditor makes and increase its strength.

- The expert systems allow the firm which uses them to reach the best possible experiences of auditor in information technology environment.

- $\quad$ The expert systems represent a documentary reference for auditor where he $\backslash$ she can use in other missions of audit.

- The expert systems can be used as a backside in order to make a decision for the experienced practiced auditorsand as a trainer for unpracticed auditors.

- The expert systems shorten the time for the beginners who need to improve their ability of making the decision.

\section{Field Study}

\subsection{The Methodology of Study}

In order to achieve the purposes of study, analytical descriptive approach which based on collecting, analyzing and explaining the information related to the main elements of study in order to build its theoretical frame. This is based on the literature of information systems which addressed the subjects of the expert systems, auditing and the fields of using expert systems in order to improve the performance of audit processes and achieve audit's quality. Through the theoretical frame, a questionnaire has been designed; it consisted of items addressing the role of expert systems in developing the performance of auditor and improving audit service quality. For testing the hypotheses of study, Five-likert scale has been used for answering questionnaire's items where No. (5) Refers to strongly agree, No. (4) To agree, No. (3) To neutral, No. (2) Disagree, and No. (1) strongly disagree).

In order to explain the results, the range of (1-1.79) has been used to indicate that the sample of study is not agree that using the expert systems contributes to develop auditor performance and improve audit service quality where (1.8-2.59) has been used to indicate that the sample of study agree at a low level that using the expert systems contributes to develop auditor performance and improve audit service quality. (2.60-3.30) has been used to indicate that the sample of study agree at a middle level that using the expert systems contributes to develop auditor performance and improve audit service quality. In addition, (3.40-4.19) has been used indicate that the sample of study strongly agree at that using the expert systems contributes to develop auditor performance and improve audit service quality. Finally, (4.20-5) has been used indicate that the sample of study agree at a middle level that using the expert systems contributes to develop auditor performance and improve audit service quality. SPSS has been used in order to analyze the data by calculating the percentage and 
arithmetic mean.

\subsection{The Population and Sample of Study}

The population of study consists of audit offices where 150 questionnaires have been distributed on various audit offices located in Irbid and Amman; 128 questionnaires have been returned back. However, 120 questionnaires have been valid for statistical analysis.

\subsection{The Statistical Methods Used in Data Analysis}

Statistical Package for Social Sciences- SPSS has been used for analyzing, and testing the hypotheses.

\subsubsection{Reliability of the Study}

For ensuring the reliability of study instrument, internal consistency variable, Cronbach Alpha, has been measured where it has ranged between (0.84-0.92); table 3 shows these treatments. Ratios have been considered suitable for the purposes of this study.

Table 3. Internal consistency variable, cronbach alpha, for study fields

\begin{tabular}{lc}
\multicolumn{1}{c}{ Field } & Internal consistency \\
\hline Auditors understand the importance of using the expert systems in & 0.86 \\
audit in information technology environment. & 0.84 \\
The expert systems and their role in developing auditor performance & \\
in information technology environment. & 0.89 \\
The expert systems and their role in improving audit service quality & \\
in information technology environment. & 0.88 \\
Total & \\
\hline
\end{tabular}

\section{Data Analysis and Testing the Hypotheses of Study}

This section of study shows the results the field study has reached and discus them in light of the purposes, questions and hypotheses of study. It will start with a detailed description of the demographic and occupational sample of study. Then, the hypotheses of study will be tested.

\subsection{Demographic Characteristics of Respondents of Questionnaire's Items}

Table 4 shows the demographic characteristics of respondents of questionnaire's items; they are as follows: Education, specialty, years of experience and designation:

Table 4. Distribution of respondents on questionnaire's items

\begin{tabular}{cccc}
\hline Variable & Category & Number & Percentage (\%) \\
\hline \multirow{3}{*}{ Education } & Diploma & 13 & $13.3 \%$ \\
& Bachelor & 56 & $46.7 \%$ \\
& Master & 17 & 14.2 \\
& Phd & 31 & 25.8 \\
Specialty & Accountancy & 100 & 83.3 \\
& Accounting Information System & 5 & 4.2 \\
& Administration & 4 & 3.3 \\
Years of Experience & Computer & 11 & 9.2 \\
& Less than 2 years & 16 & 13.3 \\
& From 2-7 years & 57 & 47.5 \\
& From 7- less than 12 & 16 & 13.3 \\
& More than 17 & 31 & 25.8 \\
Designation & Office Manager & 17 & 14.2 \\
& Partner & 56 & 46.7 \\
& First auditor & 16 & 13.3 \\
\end{tabular}


Table 4 outlines the results of analysis as follows:

\section{First: Education}

From Table 4, it is noted that 13 of respondents hold diploma degree i.e (13.3\%) of the sample of study whereas 56 of respondents hold bacholar degree i.e $(46.7 \%)$ of the sample of the study. 17 of respondents hold master degree i.e (14.2\%) of the sample of study whereas 31 of respondents hold Phd i.e (25.8\%) of the sample of study. These results indicate that the highly educated human stuffs are available according to the sample of study.

\section{Second: Specialty}

From Table 4, it is noted that the highest ratio of the sample of study is those who have the specialty of "Accountancy" and their percentage has reached $(83.3 \%)$ whereas the ratio of the respondents of "Accounting Information Systems" has reached (4.2\%). The ratio of respondents of "Administration" has reached (3.3\%) whereas the ratio of respondents of "computer" has reached $(9.2 \%)$. These results indicate that there is a high percentage of respondents who have accountancy specialty meaning that they are acquainted with the subject of disclosure.

\section{Third: Years of Experience}

From Table 4, it is noted that $13.3 \%$ of respondents have an experience of work field which is ( less than two years). Furthermore, Table indicates that the rate of individuals of study sample who have an experience ranging from (2 year to less than 7$)$ has reached $(47.5 \%)$ whereas the rate of respondents who have an experience ranging from 7 years to less than 12 ) has reached (13.3\%). the rate of respondents who have an experience ranging from 7 years to less than 12 ) has reached (13.3\%). Finally, the rate of respondents who have more than 17 year experience has reached $(25.8 \%)$. These result show that more than half of the sample of study has a low experience of work field; this will affect respondents' judgment.

\section{Fourth: Designation}

From Table 4, it is noted that the percentage of office manager has reached (14.2\%), partner (46.7 \%), first auditor $(13.3 \%)$, assistant auditor $(25.8 \%)$, respectively.

\subsection{Testing the Hypotheses of Study}

In this section, the hypotheses of study will be tested and discussed according to the four axes of study:

\section{-Testing the First Hypothesis}

It states that the auditors in the Hashemite Kingdom of Jordan understand the importance of using expert systems in audit in Information Technology environment.

To check validity of this hypothesis, means and standard deviations of items related to the first hypothesis have been extracted. They are outlined in Table below:

Table 5. Arithmetic means, standard deviations of items related to the first hypothesis in descending order according to arithmetical mean

\begin{tabular}{|c|c|c|c|c|}
\hline No. & Items & mean & $\begin{array}{l}\text { Standard } \\
\text { deviation }\end{array}$ & $\begin{array}{l}\text { Response } \\
\text { Orientation }\end{array}$ \\
\hline \multicolumn{5}{|c|}{ Using the expert systems in audit process is important for achieving the following advantages of audit process } \\
\hline 1 & Achieving quickly audit missions and processes & 4.27 & .645 & Very high \\
\hline 2 & Achieving audit missions at low cost & 4.28 & .658 & Very high \\
\hline 3 & No need for using experts & 4.20 & .693 & Very high \\
\hline 4 & $\begin{array}{l}\text { The expert systems help to protect knowledge from loss and } \\
\text { damage and maintain the occupational experience of various } \\
\text { specialized fields of audit offices. }\end{array}$ & 4.18 & .710 & High \\
\hline 5 & $\begin{array}{l}\text { The expert systems help to rationalize the personal judgment } \\
\text { and evaluation of auditor in information technology } \\
\text { environment. }\end{array}$ & 4.17 & .702 & High \\
\hline 6 & $\begin{array}{l}\text { The expert systems shorten the time for the beginners who } \\
\text { need to improve their ability of making the decision. }\end{array}$ & 4.16 & .674 & High \\
\hline 7 & $\begin{array}{l}\text { The expert systems are considered the best methods for } \\
\text { training the employees of audit offices }\end{array}$ & 4.14 & .714 & \\
\hline
\end{tabular}




\begin{tabular}{clccc}
\hline $\mathbf{8}$ & $\begin{array}{l}\text { Spreading and distributing the expert systems in audit offices } \\
\text { contribute to transfer easily the human expert }\end{array}$ & 4.13 & .668 & High \\
$\mathbf{9} \quad \begin{array}{l}\text { They help the beginners to acquire a knowledge and use those } \\
\text { systems as training backsides }\end{array}$ & 4.07 & .724 & High \\
$\quad \begin{array}{l}\text { They help to plan properly audit program } \\
\text { Total }\end{array}$ & 4.03 & .744 & $\begin{array}{l}\text { High } \\
\text { High }\end{array}$ \\
\hline
\end{tabular}

Table 5 shows arithmetical means and standard deviations of the items related to the first hypothesis. Arithmetical means range from 4.03-4.27; item No. 1 stating that" Achieving quickly audit missions and processes" has been at the first rank and its Arithmetical mean has reached 4.27 and response's orientation has been very high and this has been also for items 2 and 3 whereas item No. 10 stating that" They help to plan properly audit program" has been at the last rank and its arithmetical mean has reached 4.03; response's orientation has been high since the sample of study has agreed on the advantages and importance of using the expert systems. The total orientation of respondents which has been very high has indicated that they have agreed that using the expert systems is important in audit.

Furthermore, arithmetic mean has been compared with the standard mark (3)-the acceptance standard of the hypotheses-by using $(t)$ test as shown in Table 6.

Table 6. Arithmetical means, standard deviations and "T" test

\begin{tabular}{lcccccc}
\hline $\begin{array}{l}\text { The importance of } \\
\text { using expert systems }\end{array}$ & No. & Arithmetical mean & $\begin{array}{c}\text { Standard } \\
\text { deviation }\end{array}$ & T value & $\begin{array}{c}\text { Degrees of } \\
\text { freedom }\end{array}$ & Significance level \\
\cline { 2 - 6 } in audit & 120 & 4.16 & .663 & 191.72 & 119 & .000 \\
\hline
\end{tabular}

Table above shows that there is statistical significance illustrating that auditors in the Hashemite kingdom of Jordan understand the importance of using the expert systems in audit in information technology environment. As a result, this hypothesis stating that auditors understand the importance of using the expert systems in audit in information technology environment has been accepted.

\section{Testing the second hypothesis}

It states that using expert systems in audit operation does not contribute to improve auditor performance in Information Technology environment in the Hashemite Kingdom of Jordan.

To check validity of this hypothesis, means and standard deviations of items related to the second hypothesis have been extracted. They are outlined in Table below: 
Table 7. Arithmetic means, standard deviations of items related to the second hypothesis in descending order according to arithmetical means

\begin{tabular}{|c|c|c|c|c|}
\hline No. & Items & mean & $\begin{array}{l}\text { Standard } \\
\text { deviation }\end{array}$ & $\begin{array}{c}\text { Response } \\
\text { Orientation }\end{array}$ \\
\hline \multicolumn{5}{|c|}{$\begin{array}{l}\text { Using the expert systems contribute to develop the occupational performance of auditor in information } \\
\text { technology environment through: }\end{array}$} \\
\hline 1 & $\begin{array}{l}\text { The ability of teaching unspecialized persons and developing } \\
\text { the specialized ones who have a little experience. }\end{array}$ & 4.19 & .690 & Very high \\
\hline 2 & $\begin{array}{l}\text { Using stored human knowledge according to the expert systems } \\
\text { contributes to solve the problems at a short time }\end{array}$ & 4.15 & .706 & Very High \\
\hline 3 & $\begin{array}{l}\text { Improving the productivity of audit offices where the technical } \\
\text { experience is at the disposal of the beginners of accountants }\end{array}$ & 4.15 & .741 & Very high \\
\hline 4 & $\begin{array}{l}\text { Solving the problem of scarcity of experienced persons } \\
\text { available for performing audit missions where they help to train } \\
\text { the new auditors and enable them to acquire the experience }\end{array}$ & 4.10 & .666 & Very high \\
\hline 5 & $\begin{array}{l}\text { The expert systems contribute to form deep understanding } \\
\text { which induces the experts of audit offices for reviewing deeply } \\
\text { their practices. }\end{array}$ & 4.10 & .679 & Very high \\
\hline 6 & $\begin{array}{l}\text { The expert systems help to make decisions of unstructured } \\
\text { missions in addition to deal with uncertainty cases } \\
\text { accompanied the unstructured missions }\end{array}$ & 4.05 & .732 & Very high \\
\hline 7 & $\begin{array}{l}\text { They are useful means for providing high levels of experience } \\
\text { in case that the expert is not available. }\end{array}$ & 3.97 & .704 & Very high \\
\hline 8 & $\begin{array}{l}\text { Easiness of use and ability of learning directly and indirectly } \\
\text { from the experts }\end{array}$ & 3.85 & .657 & Very high \\
\hline 9 & $\begin{array}{l}\text { The expert systems have an ability of performing complicated } \\
\text { missions because they consist of a knowledgement of multiple } \\
\text { experts which enable them to perform these missions at a high } \\
\text { commercial level or at a level exceeding the human } \\
\text { experiences of the same field. }\end{array}$ & 4.12 & .687 & Very high \\
\hline
\end{tabular}

Table 7 shows arithmetical means and standard deviations of the items related to the second hypothesis. Arithmetical means range from 3.85-4.19; item No. 1 stating that "The ability of teaching unspecialized persons and developing the specialized ones who have a little experience." has been at the first rank and its Arithmetical mean has reached 4.19 whereas item No. 9 stating that" The expert systems have an ability of performing complicated missions because they consist of a knowledge of multiple experts which enable them to perform these missions at a high commercial level or at a level exceeding the human experiences of the same field " has been at the last rank and its arithmetical mean has reached 3.85; respondents' orientation regarding the role of the expert systems in developing audit performance has been high in all items of hypothesis.

Furthermore, arithmetic mean has been compared with the standard mark 3-the acceptance standard of the hypotheses-by using (t) test as shown in Table 8 .

Table 8. Arithmetical means, standard deviations and "T" test

\begin{tabular}{|c|c|c|c|c|c|c|}
\hline $\begin{array}{l}\text { Using the expert systems and developing the } \\
\text { occupational performance of auditor in information }\end{array}$ & No. & $\begin{array}{l}\text { Arithmetical } \\
\text { mean }\end{array}$ & $\begin{array}{l}\text { Standard } \\
\text { deviation }\end{array}$ & $\begin{array}{c}\mathrm{T} \\
\text { value }\end{array}$ & $\begin{array}{l}\text { Degrees of } \\
\text { freedom }\end{array}$ & $\begin{array}{l}\text { Significance } \\
\text { level }\end{array}$ \\
\hline technology environment & 120 & 4.12 & .687 & 145.31 & 119 & .000 \\
\hline
\end{tabular}

Table above shows that there are statistically significant differences $(0.05 \geq a)$; these indicate that using the expert systems contributes to develop the occupational performance of auditor in information technology environment. As a result, this hypothesis has been refused and the alternative hypothesis stating that using the expert systems contributes to develop auditor performance in information technology environment in the Hashemite Kingdom of Jordan has been accepted. 


\section{Testing the third hypothesis}

It states that using expert systems in audit operation does not lead to improve audit quality in Information Technology environment in the Hashemite Kingdom of Jordan.

To check validity of this hypothesis, means and standard deviations of items related to the third hypothesis have been extracted. They are outlined in Table below:

Table 9. Arithmetic means, standard deviations of items related to the third hypothesis in descending order according to arithmetical means

\begin{tabular}{|c|c|c|c|c|}
\hline No. & Items & mean & $\begin{array}{l}\text { Standard } \\
\text { deviation }\end{array}$ & $\begin{array}{c}\text { Response } \\
\text { Orientation }\end{array}$ \\
\hline \multicolumn{5}{|c|}{ Using the expert systems contribute to increase audit process quality in information technology environment through: } \\
\hline 1 & $\begin{array}{l}\text { Increasing the effectiveness of the process of making the } \\
\text { decisions through providing more suitable solutions for a } \\
\text { problem, the subject of the study }\end{array}$ & 4.27 & .648 & Very high \\
\hline 2 & $\begin{array}{l}\text { Using the expert systems contributes to decrease the time, } \\
\text { effort and cost. }\end{array}$ & 4.25 & .651 & Very high \\
\hline 3 & $\begin{array}{l}\text { The expert systems contribute to audit the data with high risks } \\
\text { such as doubtful debts' allocation, and the risks of obtaining } \\
\text { debts. }\end{array}$ & 4.09 & .756 & High \\
\hline 4 & $\begin{array}{l}\text { The time is not wasted in order to obtain unnecessary data } \\
\text { because the system request the data required for the decision } \\
\text { only }\end{array}$ & 3.99 & .716 & High \\
\hline 5 & $\begin{array}{l}\text { These systems are able to explain and justify the decisions as } \\
\text { done by human expert; this aims at enhancing user confidence } \\
\text { with the system }\end{array}$ & 3.97 & .654 & High \\
\hline 6 & $\begin{array}{l}\text { Preparing audit program at a high level of quality and } \\
\text { efficiency }\end{array}$ & 3.97 & .673 & High \\
\hline 7 & $\begin{array}{l}\text { These systems connect various data then the relationships, } \\
\text { which are useful in making decisions, are extracted }\end{array}$ & 3.93 & .742 & High \\
\hline 8 & $\begin{array}{l}\text { The personal judgment and evaluation of auditor are } \\
\text { rationalized and the system reaches objectively to the decision } \\
\text { in accordance with a set of programmed rules within the } \\
\text { system. }\end{array}$ & 3.93 & .936 & High \\
\hline 9 & $\begin{array}{l}\text { They reach to the fast optimal solution at a right time and } \\
\text { providing the reasons and amendments in order to take a } \\
\text { certain decision and they reach not only to the same solution } \\
\text { which the human expert reach to but also the optimal one. }\end{array}$ & 3.92 & .784 & High \\
\hline 10 & $\begin{array}{l}\text { These systems choose the proper evidence of reliability and } \\
\text { reduce uncertainty status i.e decreasing the rate of audit risk }\end{array}$ & 3.88 & 1.03 & High \\
\hline 11 & $\begin{array}{l}\text { Speediness of providing the reports with trust and accuracy } \\
\text { guarantee of contents }\end{array}$ & 3.84 & .870 & High \\
\hline 12 & $\begin{array}{l}\text { These systems improve decision's quality which an auditor can } \\
\text { make and increase its strength }\end{array}$ & 3.78 & 641 & High \\
\hline 13 & $\begin{array}{l}\text { They shorten the time used by assistant auditors who need to } \\
\text { improve their ability of making the decision. }\end{array}$ & 3.69 & .994 & High \\
\hline 14 & $\begin{array}{l}\text { The expert systems provide an explanation of the reasons } \\
\text { reaching him } \backslash \text { her to a certain result or reasons directed for a } \\
\text { certain question. }\end{array}$ & 3.9 & 0.784 & High \\
\hline $\begin{array}{l}\text { Using } \\
\text { quality }\end{array}$ & expert systems in audit process and increasing audit process & & & \\
\hline
\end{tabular}

Table 9 shows arithmetical means and standard deviations of the items related to the third hypothesis. Arithmetical means have ranged from 3.69-4.27; item No. 1 stating that "Increasing the effectiveness of the process of making the decisions through providing more suitable solutions for a problem, the subject of the 
study" has been at the first rank; the response orientation has been very high for the first and second items and the arithmetical mean has reached 4.27 whereas response orientation of the remaining items toward the role of expert systems in audit service quality in information technology environment has been high. Item No. 14 stating that "The expert systems provide an explanation of the reasons reaching him/her to a certain result or reasons directed for a certain question". Has been at the last rank and its arithmetical mean has reached 3.69. Respondents' general orientation has been high.

Furthermore, arithmetic mean has been compared with the standard mark (3)-the acceptance standard of the hypotheses-by using (t) test as shown in Table 10.

Table 10. Arithmetical means, standard deviations and "T" test

\begin{tabular}{ccccccc}
\hline $\begin{array}{c}\text { Using the expert } \\
\text { systems and }\end{array}$ & No. & Arithmetical mean & $\begin{array}{c}\text { Standard } \\
\text { deviation }\end{array}$ & T value & $\begin{array}{c}\text { Degrees of } \\
\text { freedom }\end{array}$ & Significance level \\
\cline { 2 - 6 } $\begin{array}{c}\text { increasing audit } \\
\text { process quality }\end{array}$ & 120 & 3.9 & 0.784 & 137.4 & 119 & .000 \\
\hline
\end{tabular}

Table above shows that there are statistically significant difference $(0.05 \geq$ a) between using the expert systems in audit process and increasing audit process quality. As a result, this hypothesis has been refused and the alternative hypothesis stating that using the expert systems in audit process leads to increase audit process quality in information technology environment in the Hashemite Kingdom of Jordan has been accepted.

\section{Testing the Fourth Hypothesis}

These items measure the limits of using the expert systems in audit processes in information technology environment.

To check validity of this hypothesis, means and standard deviations of items related to the fourth hypothesis have been extracted. They are outlined in Table below:

Table 11. Arithmetic means, standard deviations of items related to the fourth hypothesis in descending order according to arithmetical means

\begin{tabular}{|c|c|c|c|c|}
\hline No. & Items & Arithmetical mean & $\begin{array}{l}\text { Standard } \\
\text { deviation }\end{array}$ & Response Orientation \\
\hline 1 & $\begin{array}{l}\text { Increasing the cost of designing and performing } \\
\text { these systems }\end{array}$ & 4.27 & .645 & Very high \\
\hline 2 & $\begin{array}{l}\text { Varying the missions and problems which the } \\
\text { auditor faces while performing audit missions }\end{array}$ & 4.20 & 693 & Very high \\
\hline 3 & $\begin{array}{l}\text { Difficulty of updating them and accumulating the } \\
\text { experiences within the expert systems }\end{array}$ & 4.18 & .710 & High \\
\hline 4 & Lack of scientific knowledge of auditor & 4.17 & .702 & High \\
\hline 5 & Lack of practical knowledge of auditor & 4.13 & .859 & High \\
\hline 6 & $\begin{array}{l}\text { Lack of specialization of audit office in certain } \\
\text { industrial or serving sector }\end{array}$ & 4.13 & .668 & High \\
\hline 7 & $\begin{array}{l}\text { Difficulty of using them because they need } \\
\text { training }\end{array}$ & 4.7 & .742 & High \\
\hline 8 & $\begin{array}{l}\text { A necessity of connecting the electronic systems } \\
\text { of companies, the place of audit with audit } \\
\text { companies and lack of protection against viruses }\end{array}$ & 3.92 & .784 & High \\
\hline $\begin{array}{l}\text { The } \\
\text { audits }\end{array}$ & $\begin{array}{l}\text { nits of using the expert systems in audit from } \\
\text { ' point of view in Jordan }\end{array}$ & 4.16 & 0.76 & High \\
\hline
\end{tabular}

Table 11 shows arithmetical means and standard deviations of the items related to the fourth hypothesis. Arithmetical means have ranged from 3.92-4.27; item No. 1 stating that" Increasing the cost of designing and performing these systems " has been at the first rank; the arithmetical mean has reached 4.27 and the response orientation of respondents has been very high where the cost of these systems is considered one of the limits of 
using them in audit whereas item No. 8 stating that "a necessity of connecting the electronic systems of companies, the place of audit with audit companies and lack of protection against viruses" has been at the last rank and its arithmetical mean has reached 3.92 and response orientation has been high. Respondents' general orientation of hypothesis' item has been high.

Furthermore, arithmetic mean has been compared with the standard mark (3)-the acceptance standard of the hypotheses-by using (t) test as shown in Table 12.

Table 12. Arithmetical means, standard deviations and "T" test

\begin{tabular}{ccccccc}
\hline $\begin{array}{c}\text { The limits of using expert } \\
\text { systems in audit from }\end{array}$ & No. & $\begin{array}{c}\text { Arithmetical } \\
\text { mean }\end{array}$ & $\begin{array}{c}\text { Standard } \\
\text { deviation }\end{array}$ & T value & $\begin{array}{c}\text { Degrees of } \\
\text { freedom }\end{array}$ & $\begin{array}{c}\text { Significance } \\
\text { level }\end{array}$ \\
\cline { 2 - 6 } $\begin{array}{c}\text { auditors' points of view in } \\
\text { Jordan }\end{array}$ & 120 & 3.88 & 0.76 & 136.33 & 119 & .000 \\
\hline
\end{tabular}

Table above shows that there are statistically significant differences $(0.05 \geq a)$; these results indicate that from Jordanian auditors' points of view, there are limits which hinder the use of the expert systems in audit. As a result, this hypothesis has been accepted.

\section{Results and Recommendations}

\subsection{Results}

The study has reached to the following results:

Using the expert systems in audit achieve advantages and benefits contributing to develop audit profession in the Hashemite Kingdom of Jordan in information technology environment. Furthermore, using such systems achieves an accuracy and speediness of performing audit process through their role in assisting auditors regarding the process of making decisions and planning properly in information technology environment.

Using the expert systems in audit process contributes to improve auditor performance in information technology environment in the Hashemite Kingdom of Jordan where such systems address the problem of scarcity of experienced auditors who are specialized in performing audit missions. Such systems help auditors to acquire quickly an experience.

Using the expert systems in audit process leads to increase audit process quality in information technology environment and contributes to perform quickly audit missions. They also help to rationalize the personal judgment and evaluation of auditor in information technology environment where helshe reaches objectively to a decision because he $\backslash$ she depends on a programmed knowledge base within the system. Consequently, auditor's report will be more trusted. Using the expert systems contributes to decrease the cost of audit process through completing audit missions because these missions are performed quickly and do not need to extra time. Furthermore, the costs associated with improper decisions are avoided due to systems 'objectivity and accuracy of reaching to these decisions. They also help to plan a suitable audit program, and decrease the time and effort required in addition to submit the report with accuracy and trust guarantee. Finally, the expert systems help to choose the proper evidence of reliability and decrease uncertainty status i.e decreasing the rate of audit risk.

There are limits which hinder using the expert systems in audit in information technology systems in the Hashemite Kingdom of Jordan.

Since the use of information technology in Jordanian business sector is developing, the auditor need to develop his/her performance through using new information technology systems for performing audit missions.

In light of the advantages and features of using the expert systems in audit, auditor can overcome the problems he/she may face in audit process if helshe use such systems.

Most of audit missions are listed in semi-structured missions' scope where the expert systems can be used for performing such missions.

There are various important fields where the expert systems can be used in audit process; these fields are associated with internal control system, audit planning system, electronic operation system. Furthermore, such systems can be used by auditor in order to structure his/her opinion on establishment's continuation.

\subsection{Recommendations}


It is recommended that it is necessary to develop the occupational performance of auditor in information technology environment through conducting training specialized practical courses of using information technology application in audit process and the respective programs.

It is recommended that an auditor shall know the importance, role and benefits of using the expert systems in audit process and the possibility of using them during audit process through conducting theoretical training courses related to these subjects.

It is recommended that academic plans of Jordanian universities shall be developed and shall include subjects related to the expert systems.

It is recommended that the fields where the expert systems can be used in audit depend on auditor' ability. This can be performed by identifying the steps of each field as well as the requirements of audit process in order to achieve the goal desired then program it according to the requirements of expert system programs. Such matter needs scientific and practical qualification of auditor regarding the expert systems.

\section{References}

Altman, E., Maroco, G., \& Varetto, F. (1994). Corporta Distress Diagnosis: comparisons using linear discriminate analysis and neural networks. Journal of Banking and Finance, 18(5), 505-529. http://dx.doi.org/10.1016/0378-4266(94)90007-8

Amin, A. (2005). Reviewing and Auditing information systems. University House. Al-exandria.

Atiya, A. F. (1995). Banking prediction for Credit Risk using neural network: A Survey and new result. IEEE, $76(11), 51-53$.

Callen, G, L, Kwan, C. C. Y., \& Tuan, Y. (n. d.). Neural network forecasting of Quarterly Accounting Earning.

Etheridg, H. L., Sriram, R. S., \& Hsu, H. Y. K. (2000). A Comparison of selected artifical neural networks that help Auditors evaluate client financial viability. Decision Sciences, 31(2), 531-550. http://dx.doi.org/10.1111/j.1540-5915.2000.tb01633.x

Fulton, C., \& Garcau, L. (1996). Beyond expert system: neural networks in Accounting. National Public Accountant, 41(6), 26-30.

Heafke, C., \& Haldenstein, C. (1996). Forecasting Austrian IPO, An Application of linear and neural network Error-correction models. Journal of Forecasting, 15, 237-521. http://dx.doi.org/10.1002/(SICI)1099-131X(199604)15:3<237::AID-FOR621>3.0.CO;2-5

Hill, T., Marquez, L., O'Conner, M., \& Remus, W. (1994). Artificial neural network models for forecasting, and decision making. International Journal of Forecasting, 10(1), 5-15. http://dx.doi.org/10.1016/0169-2070(94)90045-0

Kosivaara, E. (2000). Artifical neural network models for predicting patterns in auditing monthly balances. Journal of the Operational Research Society, 51(9), 1060-1069.

Lachtermacher, G., \& Fuler, J. (1995). Back-propagation in time series forecasting. Journal of Forecasting, 14(4), 381-393. http://dx.doi.org/10.1002/for.3980140405

Lin, J. W., Hwang, M, I., \& Backer, J. D. (2003). Afuzz neural network for assessing the risk of fraudlent financial Reporting. Managerial Auditing Journal, 18(8), 657-665. http://dx.doi.org/10.1108/02686900310495151

Mubarak, S., Al-Din, A., \& Radih, M. S. (1996). Designing Accounting Expert System and Assessing The activity of Banking Assumption-A Theoretical Study. Journal of General Administration, 36(3).

Oison, D., \& Mossman, C. (2003). Neural network forecasts of Canadian stock returns using Accounting ratios. International Journal of Forecasting, 19(3), 453-465. http://dx.doi.org/10.1016/S0169-2070(02)00058-4

Post, G. V., \& Anderson, D. L. (2003). Management information Systems (3rd ed.). McGraw-Hill Lrwin, Inc.

Shadli, S. S. (2004). The effect of the expert systems on increasing the efficiency and effectiveness of external audit. MA thesis, Faculty of Economics and administration, King AbdulAziz University.

Siegel, P. H., Omer, K., Korvin, A., \& Zebda, A. (1998). Applications of Fuzzy Sets and the Theory of Evidence to Accounting. England: London: 11. J A L Press Inc.

Tam, K. Y., \& Kiang, M, Y. (1992). Managerial application of neural networks: the Case of the Bank failure predictions. Management Science, 38(7), 926-947. 
Trigueiros, D., \& Traffer, R. (1996). Neural networks and Empirical Research, in accounting. Accounting and Business Research, 26(4), 347-355. http://dx.doi.org/10.1080/00014788.1996.9729524

Turban, E., Aronson, J. E., \& Bolloju, N. (2001). Decision Supported system and intelligent system (6th ed.).

Wilson, R. L., \& Shared, R. (1994). Bankruptcy prediction using neural network. Decision Support System, 11(5), 545-557. http://dx.doi.org/10.1016/0167-9236(94)90024-8

Zmijewski, M. E. (1984). Methodological issue related to the Estimation of financial distress predation models. Journal of Accounting Research, 122, 59-82. http://dx.doi.org/10.2307/2490859

\section{Copyrights}

Copyright for this article is retained by the author(s), with first publication rights granted to the journal.

This is an open-access article distributed under the terms and conditions of the Creative Commons Attribution license (http://creativecommons.org/licenses/by/3.0/). 